\title{
"Medical-Related Financial Distress" and Health Care Finance: A Reply to Professor Melissa Jacoby
}

\author{
Stephen J. Ware*
}

Melissa Jacoby starts her contribution to this symposium describing herself "as a debtor-creditor researcher and not a health law expert." Her characteristic modesty notwithstanding, she is an expert (perhaps the expert) on the intersection between health and debtor-creditor law or, to use her phrase, "medical-related financial distress." "2 Professor Jacoby has published several careful articles on the subject. ${ }^{3}$ In this substantial body of work, she emphasizes "the entanglement between health care and the debtor-creditor system," particularly the strong connection between health problems (illness or injury) and bankruptcy. ${ }^{5}$ For instance, Professor Jacoby and her co-authors report a major study which found that "[n]early half of all bankruptcies involved a medical

\footnotetext{
Professor of Law, University of Kansas School of Law. Thanks to Melissa Jacoby, Tom Stacy, Elizabeth Weeks, Rick Levy, and David Hyman.

1. Melissa B. Jacoby, Individual Health Insurance Mandates and Financial Distress: A Few Notes from the Debtor-Creditor Research and Debates, 55 U. KAN. L. REV. 1247, 1247 (2007).

2. Id. at 1249; Melissa B. Jacoby \& Elizabeth Warren, Beyond Hospital Misbehavior: An Alternative Account of Medical-Related Financial Distress, 100 Nw. U. L. REV. 535, 536 (2006).

3. In addition to the two articles in previous footnotes, see, e.g., Melissa B. Jacoby, Generosity Versus Accessibility: Bankruptcy, Consumer Credit and Health Care Finance in the US, in CONSUMER BANKRUPTCY IN A GLOBAL PERSPECTIVE 282 (Niemi-Kiesiläinen, Ramsay, \& Whitford, eds. 2003); Melissa B. Jacoby, The Debtor-Patient Revisited, 51 ST. LouIS U. L. J. 307 (2007); Melissa B. Jacoby, Bankruptcy Reform and the Costs of Sickness: Exploring the Intersections, 71 Mo. L. ReV. 903 (2006); Melissa B. Jacoby, Not-for-Profit Hospital Billing and Collection: Resisting Quick Legal Fixes, 3 AM. HEART HOSP. J. 36 (2005); Melissa B. Jacoby, The Debtor-Patient: In Search of Non-Debt-Based Alternatives, 69 BROOK. L. REV. 453 (2004); Melissa B. Jacoby, Does Indebtedness Influence Health? A Preliminary Inquiry, 30 J. L. MED. \& ETHICS 560 (2002); Melissa B. Jacoby, Collecting Debts from the Ill and Injured: The Rhetorical Significance, but Practical Irrelevance, of Culpability and Ability to Pay, 51 AM. U.L. REV. 229 (2001); Melissa B. Jacoby et al., Rethinking the Debates over Health Care Financing: Evidence from the Bankruptcy Courts, 76 N.Y.U. L. REV. 375 (2001). 454.

4. Jacoby, The Debtor-Patient: In Search of Non-Debt-Based Alternatives, supra note 3, at

5. Jacoby et al., Rethinking the Debates over Heath Care Financing: Evidence from the Bankruptcy Courts, supra note 3, at 377 (noting that "many families declared bankruptcy in the aftermath of illness or injury").
} 
problem." Another theme in Professor Jacoby's work is that the patient's lack of sufficient insurance to cover the full cost of these medical problems is a major part of the connection between health problems and bankruptcy. ${ }^{7}$ Generally, a patient who lacks sufficient insurance is personally liable to pay for the medical care she receives and thus "has a dual role of patient and debtor, with the latter role propelling her into the commercial debtor-creditor world.",

In her contribution to this symposium, Professor Jacoby takes her prior research and learning and applies them to the Massachusetts Plan and other "individual mandates," that is, legal requirements that individuals buy health insurance. ${ }^{9}$ Individual mandates are an attempt to move in the direction of "universal coverage," a scenario in which everyone has at least minimal health insurance. The Massachusetts Plan combines this individual mandate with public funding to help lowincome people comply with it. ${ }^{10}$ Whether the Massachusetts Plan will

6. Id. ("Nearly half of all bankruptcies involved a medical problem, and certain groupsparticularly women heads of households and the elderly-were even more likely to report a health-related bankruptcy."). Professor Jacoby and her co-authors recognize that their "research method relies heavily on self-reporting by debtors, and it is possible that debtors perceive the role of medical problems differently from an omniscient observer. Some might overstate the role of ill health because it seems to be a more acceptable explanation than, for example, overspending." Jacoby \& Warren, supra note 2 , at 547 . Other data, however, confirm the connection between health problems and bankruptcy. See 151 Cong. Rec. S2053, 2078 (daily ed. Mar. 4, 2005) (reprinting a letter and materials to Senator Charles E. Grassley from William E. Moschella) (noting that medical debt was listed in $46 \%$ of a sample of no-asset chapter 7 cases); Ed Flynn \& Gordon Bermant, The Class of 2000, AM. BANKR. INST. J., Oct. 2001, at 20, 20 (finding 56.2\% of chapter 7 no-asset bankruptcy filers with medical debt on bankruptcy schedules); Aparna Mathur, for AMERICAN ENTERPRISE INSTITUTE, Medical Bills and Bankruptcy Filings 5-7 (2006), http://www.aei.org/ publication 24680 (finding "that up to 27 percent . . of all [bankruptcy] filings involve cases where medical bills were the primary form of debt").

7. Insufficient insurance is only part of the connection because "the income effects of health care problems, especially over the long term, are often more financially devastating than the medical bills themselves." Jacoby, Rethinking the Debates over Health Care Financing: Evidence from the Bankruptcy Courts, supra note 3, at 410.

Even if insurance pays every cent of the direct medical costs, recovery from an illness or accident can cause a temporary problem-a few lost work days-or more permanent problems with longer-term professional repercussions. The financial effects of heart attacks and strokes, progressively worsening asthma, or cancer only may begin with medical bills. Such medical problems may leave a wage eamer with a sharply reduced or nonexistent earning capacity. Income supplement programs, such as social security disability and workers' compensation, offer some assistance, but the programs are spotty in coverage and fall short in providing benefits.

Id. at 407 .

8. Jacoby, The Debtor-Patient: In Search of Non-Debt-Based Alternatives, supra note 3, at 472 .

9. Jacoby, supra note 1 , at 1249 .

10. See, e.g., Elizabeth A. Weeks, Failure to Connect:The Massachusetts Plan for Individual Health Insurance, 55 U. KAN. L. REV. 1283, parts II.B-C (2007). 
succeed in moving significantly toward universal coverage (and, if so, at what cost) remains to be seen. ${ }^{11}$ Professor Jacoby asks us to put aside these doubts and assume that the Massachusetts Plan decreases the number of uninsured people in Massachusetts and "hook[s] previously uninsured people into health care delivery networks." "12 This assumption, Professor Jacoby says, "still leaves us with several questions, the most pressing of which (at least for the purposes of my research) is whether the Massachusetts Plan protects its citizens from medical-related financial distress."13

Consider, for a moment, that goal of Massachusetts: "protect[ing] its citizens from medical-related financial distress." This is quite an ambitious goal. If a duty to pay even the smallest amount can cause some degree of distress, then completely protecting people from medicalrelated financial distress would require unlimited free medical care. ${ }^{14}$ But even if the Commonwealth of Massachusetts (or any other government) wanted to write a blank check to provide unlimited free medical care, the government's funds to do that would ultimately come from taxes paid by its citizens. As Professor Jacoby recognizes, "[b]y expending taxpayer resources and requiring greater out-of-pocket outlays from citizens through the individual mandate of the Massachusetts Plan, the Commonwealth of Massachusetts does not necessarily make its citizens more financially secure; it might just be shifting around the insecurity." 15 This insight highlights an important truth that is too easily lost in discussions of medical care: the cost of providing such care has to be paid by somebody.

I, for one, would like to see Professor Jacoby grapple with that important truth. She has, as noted above, published several careful articles about medical-related financial distress. She and her co-author, Professor Elizabeth Warren, have described medical-related financial distress as a "pervasive problem.", They trace this problem to

11. For an accessible and skeptical view, see Michael Tanner, No Miracle in Massachusetts: Why Governor Romney's Health Care Reform Won't Work, Cato Briefing Paper No. 97, June 6, 2006, available at http://www.cato.org.

12. Jacoby, supra note 1 , at 1250 .

13. The quoted language is from the draft of Professor Jacoby's paper to which I was asked to reply. The relevant passage of her final article has since been changed to: "This still leaves the question of whether the Massachusetts Plan makes progress toward the second underlying goal, which is to protect individuals against financial risk. I refer to this risk more generally as medicalrelated financial distress." Id. at 1248-49.

14. It might also require unlimited income-replacement insurance for income not eamed due to medical problems.

15. Jacoby, supra note 1 , at 1251.

16. Jacoby \& Warren, supra note 2 , at 584. 
"structural limitations of health care finance"17 and suggest that they would like to "make meaningful inroads into" this problem. ${ }^{18}$ But nowhere in Professor Jacoby's published writings do I find her endorsing any way to do this.

In short, I have not seen Professor Jacoby take a side, or craft her own position, on health care finance. This, in my view, is a shame. It is a shame because how we pay for medical care in the United States is one of the major issues of our day. Debate over this issue includes many voices, some better informed than others. And some of the loudest voices-those with the most influence-are those of special interest groups pursuing their agendas at the expense of the broader public interest. ${ }^{19}$ So it is a shame when a well-informed voice, uncorrupted by any special-interest agenda, like Professor Jacoby's is silent on this major issue.

On a personal level, I say: Melissa, you've made a diagnosis and determined that medical-related financial distress is merely a symptom, while health care finance is the location of the disease. Now it's time for you to join the task of finding a cure. The time has come for you to move from the descriptive to the normative. In your next paper, don't let your caution and modesty keep you from taking a stand.

Now that I have posed this friendly challenge for Professor Jacoby, I owe her an explanation of how daunting I (a novice with respect to health $\operatorname{law}^{20}$ ) think it is. To put it another way, I think Professor Jacoby's description of "medical-related financial distress" as a "pervasive problem"21 is not merely a throwaway line but rather a claim that raises important, even philosophical, questions. And her goal of "mak[ing] meaningful inroads into"22 the problems caused by "structural limitations

17. Id. at 563 .

18. Id. at 584.

19. See, e.g., Clark C. Havighurst \& Barak D. Richman, Distributive Injustice(s) in American Health Care, LAW \& CONTEMP. PROBS., Autumn 2006, at 7, 9-10, 62 (describing how providers of medical care have successfully lobbied for laws that advance their interests, and those of wealthy people, contrary to the interests of others in society); Timothy Stoltzfus Jost, Why Can't We Do What They Do? National Health Reform Abroad, 32 J. L. MED. \& ETHICS 433, 438-39 (2004) (noting the American Medical Association has opposed adopting universal health insurance and business and employer groups have opposed health care reform).

20. While Professor Jacoby and I both teach debtor-creditor law, I have not written on her specialty, the intersection between health and debtor-creditor law. This short reply to Professor Jacoby consists largely of questions to her, rather than of my own normative views on health care finance. That said, my questions do reflect libertarian premises about the role of government generally and about health law in particular.

21. Jacoby \& Warren, supra note 2 , at 584 .

22. Id. 
of health care finance" 23 commits her to a scholarly agenda much broader than the empirical and doctrinal aspects of debtor-creditor and health law. It is an agenda that confronts grand issues of political philosophy and economics, that is, what used to be called "political economy."

The starting place for this scholarly agenda is Professor Jacoby's claim that "medical-related financial distress" is a "pervasive problem." This broad claim can be separated into two more specific claims: (1) financial distress can be a "pervasive problem," and (2) "medical-related financial distress" is significantly different from other financial distress. Professor Jacoby needs to support both these claims.

The first claim - that financial distress can be a pervasive problemis merely a truism if financial distress is defined broadly enough to encompass all situations in which a person's wants exceed that person's means. How many people can afford everything they want? Imagine a very wealthy person who owns homes in New York, Paris, and London but also wants a home in Tokyo. If she does not have enough money for that fourth home then she is suffering from "financial distress" if that term is defined broadly enough to encompass all situations in which a person's wants exceed that person's means. If Professor Jacoby does not go this far, then her first task, it seems to me, is to define what she means by "financial distress." By how much do a person's wants have to exceed her means to achieve those wants for this gap to qualify as "financial distress"?

23. Id. at 563 .

24. Id. at 584 .

25. Some who read a draft of this paper suggest defining "financial distress," not as wants exceeding the means to pay for them, but rather as debts exceeding the means to pay for them. This debt-oriented definition of financial distress can be assessed by considering two individuals who each want something, such as a new car, that neither can afford. The first person goes without a new car, while the second person gets a new car by incurring debts she cannot pay. A debt-oriented definition of "financial distress" would say that the second person is in financial distress, while the first person is not. I am skeptical of such a definition. Do those who propose it deny that going without what one wants, but cannot afford, can be a source of distress? And if this "going without" is caused by lack of finances then what sort of distress is it but financial distress?

Moreover, if lawmakers seek to ameliorate financial distress, then a debt-oriented definition of financial distress is troubling because it guides the law's relief to the spendthrifts but not the stoics. Why provide relief to those who borrow to get what they cannot afford, but not to those who go without what they cannot afford? Perhaps Professor Jacoby's answer begins with her survey of several studies indicating that

indebtedness may be a determinant of health. Some of the studies also suggest mechanisms such as stress or reduced access to health-maximizing goods and services to explain such a relationship. Several of the studies suggest that health concerns arise not by the mere presence or absence of debt, but rather the magnitude of the debt as compared to income.

Jacoby, Does Indebtedness Influence Health? A Preliminary Inquiry, supra note 3, at 564. Perhaps these studies are the start of a showing that the stoics who go without their wants tend to enjoy better 
Alternatively, Professor Jacoby might acknowledge that many people have virtually unlimited wants so she might define "financial distress" not with reference to wants, but solely with reference to means. In other words, "financial distress" is just another way of saying "poor." But even the claim that poverty is a "pervasive problem" turns entirely on the definitional question of how poor counts as "poor." The more broadly we define "poor," the more pervasive the problem of poverty becomes. And if "financial distress" means "poor" then the problem of financial distress seems to be becoming steadily less pervasive as the wealth of ordinary people has increased over the centuries.

Professor Jacoby cannot avoid the task of defining "financial distress" by confining her subject to "medical-related financial distress." Even if one is concerned only with "medical-related financial distress," defining that term raises the same challenges as defining financial distress. Is "medical-related financial distress" experienced by everyone who lacks some level of wealth or is it experienced by people whose medical wants far exceed their means to achieve those wants? Which of these is the "pervasive problem" to which Professor Jacoby refers? Again, how pervasive the problem is turns entirely on the definitional question of how poor (or how big a gap between wants and means) counts as "distress." So Professor Jacoby's claim that medical-related financial distress is a pervasive problem requires her to do all the work inherent in claiming that any kind of financial distress can be a pervasive problem. In addition, it requires her to do the work of explaining why medical-related financial distress is significantly different from other financial distress.

Is the distress that comes from unmet medical wants significantly different from (and worthy of different treatment than) the distress that comes from other unmet wants? We all have more compassion for the person who will die today unless she gets the medical care she wants than the person whose distress comes from her unmet want for a fourth home. But consensus on these extreme cases is not sufficient to establish that the distress from unmet medical wants is generally worthy of different treatment from the law than the distress from other unmet wants. Who is to say that one person's want for medical care expected to extend her life for a year or two is more worthy than another person's want for a college education or a safer neighborhood in which to raise her children?

health than the spendthrifts who obtain their wants (at least temporarily) by borrowing beyond their means. And perhaps this health difference will lead Professor Jacoby to conclude that the law's relief ought to be guided toward the (poor-health) spendthrifts but not the (good-health) stoics. 
A sustained focus on a single type of human wants, whether it be medical care or anything else, often has the unfortunate tendency of making that type of wants seem more important than other wants. Those who focus on medical care tend to

have a partiality for the field and want to give it pride of place in competition with other goods and services. Armed with their institutional bias, they believe that the field of health should attract greater resources than other areas, for example, education and nutrition, and they are likely to invent or endorse schemes of regulation that require extensive subsidies of health care. ${ }^{26}$

It is only when we remind ourselves that resources devoted to one type of wants are not available to satisfy other types of wants that we can appreciate the ever-present necessity to make difficult tradeoffs. And it is only when we remind ourselves that our own experiences (both personal and professional) may bias us toward the wants we have (or see frequently) that we can appreciate the legitimacy of others' different perspectives. So Professor Jacoby's claim that "medical-related financial distress" is a "pervasive problem"27 requires her to explain what makes it a more pervasive problem than financial distress arising from other unmet wants.

One view is that wants for medical care are better described as "needs" than "wants" and that this distinguishes them from other wants. After all, medical care is often needed to preserve life itself. Here again, though, we must caution ourselves about imposing our values on others. Few situations are as stark as " $\mathrm{X}$ medical treatment will certainly save this patient's life and without it she will certainly die today." Most situations are more nuanced with uncertainty about the benefits of the treatment in question and whether the expected benefits are worth the costs. And even if it is certain that a particular treatment will save a life, costs still must be considered. " $[\mathrm{N}]$ o society can afford to spend all of its wealth to prolong a single life for a single day; nor can it afford the more 'modest' goal of spending all its wealth on health care, to the exclusion of all other ends." 28 So tradeoffs are inevitable even if one characterizes wants for medical care as "needs." These needs must compete for scarce resources with other needs, such as food, clothing and shelter-things every bit as necessary for survival as medical care. So even if Professor

26. Richard A. EPStein, Mortal PERIL 5 (1997). For examples of this, see, e.g., Havighurst \& Richman, supra note 19 , at 7 .

27. Jacoby \& Warren, supra note 2 , at 584.

28. EPSTEIN, supra note 26, at 6-7. 
Jacoby is prepared to make the needs/wants distinction, ${ }^{29}$ her claim that medical-related financial distress is a "pervasive problem" ${ }^{\text {"30 }}$ still requires her to explain what makes it a more pervasive problem than, for example, food-related financial distress (hunger) or shelter-related financial distress (homelessness). ${ }^{31}$

A common egalitarian position is to decree that some basic minimum standard of all needs (including food, clothing, shelter and medical care) must be guaranteed to every member of a "just and humane society." 32 Perhaps Professor Jacoby will take this position, ${ }^{33}$ and go on to say that in today's United States most everyone has their basic needs met with

29. See, e.g., Russell Korobkin, Determining Health Care Rights from Behind a Veil of Ignorance, 1998 U. ILL. L. REV. 801 (1998).

According to Rawls, certain social resources can be classified as "primary goods," meaning that virtually all individuals value them despite interpersonal differences in desires and life goals. They are "things which it is supposed a rational man wants whatever else he wants." Because of their universality, individuals operating behind the veil of ignorance (who, thus, do not know what their life goals are) would desire these items. Among the categories of primary goods, according to Rawls, are liberties, rights, opportunities, powers, wealth, and income. Although not mentioned specifically by Rawls, health care, it seems, could readily be added to this list: good health is a prerequisite to (or at least an advantage in) the pursuit of any plausible set of life goals. Because health care contributes to good health (although the former is not, of course, the only input of the latter), it would be viewed as a "good" by all individuals, even those operating behind the veil.

Id. at 806 (citing JOHN RAWLS, A THEORY OF JUSTICE (1971)).

30. Jacoby \& Warren, supra note 2, at 584 .

31. Alternatively, Professor Jacoby may ultimately conclude that medical-related financial distress is no more pervasive a problem than other types of financial distress. She may even conclude that is not meaningfully distinct from other types of financial distress. One of Professor Jacoby's most recent publications states that "[m]edical debt and delinquency are surprisingly widespread but often not catastrophic and may be incurred in a broader context of financial vulnerability." Jacoby, The Debtor-Patient Revisited, supra note 3, at 323-24. She raises the possibility "that the most common medical debts do not differ significantly in magnitude from debts arising from other necessities that result in debt on credit reports, such as utilities, shelter, food, and clothing." Id. at 323.

32. EPSTEIN, supra note 26, at 29-30 (quoting ALAIN ENTHOVEN, THEORY AND PRACTICE OF MANAGED COMPETITION IN HEALTH CARE FINANCE 2-4 (1988)).

33. Professor Jacoby has expressed concern about people who "forego[]" "health maximizing goods and services," Jacoby, Bankuptcy Refom and the Costs of Sickness: Exploring the Intersections, supra note 3 , at 915 , as by "skimping on various things when money ran short, including food, doctors' appointments, and prescription drugs." Id. at n.58. See also Jacoby, Does Indebtedness Influence Health? A Preliminary Inquiry, supra note 3, at 564 (stating that "debt burden may hinder the borrower from making health-maximizing choices."). Although I do not believe Professor Jacoby has defined "health maximizing," it sounds like a reference to something higher than just a basic minimum level of health-related goods and services. It sounds like the optimal level of such goods and services. Guaranteeing this "health maximizing" level to each member of society goes beyond the egalitarian position of guaranteeing only a basic minimal level of them. While individuals who prioritize health can pursue health-maximization at the expense of other personal goals, a health-care specialist who would have the law incentivize everyone to similarly prioritize health is in danger of exhibiting the "institutional bias" described above by Richard Epstein. See supra text accompanying note 26. 
respect to food, clothing and shelter, but not with respect to medical care, so "financial distress" arising from those other needs is not as pervasive or pressing a problem as medical-related financial distress. ${ }^{34}$ Taking this egalitarian position entails logical consequences. Recognizing rights necessitates the imposition of correlative duties. ${ }^{35}$ If any person has the right to food, clothing, shelter and medical care, then some other person must have the duty to provide these things. The egalitarian position imposes on some people the duty to provide the wealth needed to meet others' basic needs. Is this a legal duty or merely a moral duty? If Professor Jacoby holds that it is only a moral duty then she can contribute to the appropriate charities and exhort others to do the same. But if Professor Jacoby holds that it is a legal duty to guarantee basic medical care to each member of this society, then she will need to specify what must occur to fulfill this duty. I suppose it is possible to enforce such a duty through lawsuits by and against private parties, ${ }^{36}$ but the far more common vision for fulfilling this duty is through public funding, that is, government-subsidized medical care. If Professor Jacoby goes this route then she must answer two questions: (1) who is entitled to government-subsidized medical care, and (2) how is that subsidy to be delivered?

On the first question, who is entitled to government-subsidized medical care, common answers are the poor, the sick (people with

34. Relatedly, the food and shelter needed to keep any individual alive are relatively inexpensive. By contrast, the medical care needed to keep certain individuals alive is enormously expensive. The enormity of that expense and the difficulty (impossibility?) of obtaining sufficient insurance to cover it can make it (rather than food or shelter) a source of stress even for people who are not poor. As Professor Jacoby says, "people who consider themselves middle class and have health insurance now believe it is possible that they could go-to use the title of this symposium'from risk to ruin' when they get sick." Jacoby, The Debtor-Patient Revisited, supra note 3, at 309.

35. See BLACK'S LAW DiCTIONARY 453 (5th ed. 1979) (defining "duty" as "the correlative of right" and noting that "wherever there exists a right in any person, there also rests a corresponding duty upon some other person or upon all persons generally."); WESLEY NEWCOMB HOHFELD, FundamentAL LEGAL CONCEPTIONS AS APPLIED IN JUDICIAL REASONING 36-38 (Walter Wheeler Cook ed. 1919) (conceiving of "rights" and "duties" as correlatives).

36. Interestingly, the common law had an element of this until about fifty years ago when written insurance policies replaced implied contracts between doctors and patients.

Because physicians typically do not negotiate fees in advance with patients, when, prior to widespread insurance, physicians sued for fees, courts determined the implied payment terms according to what the suing physician and others in the community normally charged. Part of that calculation was the accepted practice, prior to widespread insurance, of charging sliding-scale fees based on ability to pay. Almost all of this litigation focused on whether physicians could charge more to wealthier patients, but implicitly courts also required physicians to charge poor patients less.

Mark A. Hall, Paying for What You Get and Getting What You Pay for: Legal Responses to Consumer-Driven Health Care, LAW \& CONTEMP. ProBS. Autumn 2006, at 159, 164. 
especially severe or chronic medical problems ${ }^{37}$ ) and the elderly. ${ }^{38}$ I will discuss each of these three groups in turn.

If Professor Jacoby favors government-subsidized medical care for the poor, then she must grapple with the questions of who is poor enough to receive a subsidy and how much of a subsidy will be provided. Of course, these are enormously controversial topics that implicate the grand question that has divided Left and Right for at least a century, the extent to which government should redistribute wealth from those who have more of it to those who have less.

If Professor Jacoby favors government-subsidized medical care for the sick (regardless of the sick person's wealth) then she must grapple with another enormously controversial question, the extent to which government should mitigate the inequalities that would otherwise result from our different bodies. Wilt Chamberlain earned more money than the average person (and even more than the average professional basketball player) due, in part, to his body. ${ }^{39}$ Having a body that is like Chamberlain's - exceptionally tall and strong-surely makes it easier to acquire wealth in a free market. The same can be said of a body that is exceptionally attractive, or exceptionally intelligent. All these bodily traits are worth money. Should government subsidize people whose bodies are, through no fault of their own, especially lacking in any of these respects? Is that question different (in any important way) from the question whether government should subsidize people whose bodies are especially prone to severe or chronic medical problems ${ }^{40}$

37. See, e.g., Timothy Stoltzfus Jost, Our Broken Health Care System and How to Fix It: An Essay on Health Law and Policy, 41 WAKE FOREST L. REV. 537 (2006). Jost writes:

In any given year, a very small proportion of the population is responsible for most health care costs, while the vast majority of the population experiences few, if any, health care expenses. The most expensive one percent of the population is responsible for over a quarter of health care costs; the most expensive five percent is responsible for over half. Conversely, the least expensive half of the population accounts for less than three percent of health care expenditures.

At all ages, persons with chronic mental and physical disabilities are responsible for most health care spending. Id. at 542 .

38. Current law in the United States does all three. Examples are Medicaid (subsidizing the poor), community rating and other laws prohibiting insurers from discriminating based on genetics or pre-existing conditions (subsidizing the sick), and Medicare (subsidizing the elderly). For an excellent summary of these and other laws, see id. at 555-65.

39. See RoBERT NozICK, ANARCHY, STATE, AND UTOPIA 160-64 (1974).

40. If so, does this difference depend on a coherent distinction between "wants" (e.g., a body as tall and strong as Chamberlain's), and "needs" (e.g., a body that will support some minimum length and quality of life)?

For a thoughtful suggestion "that individuals operating behind the veil of ignorance would likely favor a society with community rating" (one way of subsidizing people whose bodies are especially 
Finally, if Professor Jacoby favors government-subsidized medical care for the elderly (regardless of the elderly person's wealth or health) then she must grapple with yet another enormously controversial topic, redistribution from the have-nots to the haves. Why should the medical care of a relatively wealthy and healthy 68 -year-old be subsidized by taxes on a relatively poor and sick 48 -year-old? ${ }^{41}$ Also, there is the charge that too many of our health-care dollars are spent on end-of-life patients in the Intensive Care Unit and too few of them are spent on the earlier years when the benefits of each additional dollar spent are likely higher. ${ }^{42}$

Professor Jacoby might say that, not only should the poor, sick and elderly be entitled to government-subsidized medical care, but everyone should be entitled to government-subsidized medical care. Advocates of such "universal health care" programs must answer all three previous sets of questions (those relating to the poor, sick and elderly) because such programs inevitably require decisions about the extent to which they redistribute wealth and the limits on the medical care that will be

prone to severe or chronic medical problems), see Korobkin, supra note 29, at 803.

41. The usual answer is greater political support for government programs that pay everyone as opposed to paying only those who really need it. See, e,g., DAVID A. HYMAN, MEDICARE MEETS MEPHISTOPHELES (2006).

If Medicare were wholly means-tested, it would be instantly transformed into a program for poor seniors, instead of one for the poor, the wealthy, and everyone in between. Once the Medicare program does not include all the elderly, it becomes much easier for legislators to impose significant funding and benefit cuts, and the political punch of proMedicare demagoguery becomes much less powerful when all that is at stake is the health and welfare of poor people.

Id. at 89

42. See, e.g., EPSTEIN, supra note 26, at 68.

Investing heavily in heroic measures after the onset of serious illness reduces the resources available for nutrition, exercise, and safety - activities that could increase health and thus forestall the ultimate day of reckoning. The reduced funds available when contingencies occur need not come at the expense of comfort; forswearing heroics and lengthy stays in the ICU should suffice.

So understood, the basic form of the choice is: (A) have an expected life of 80 years, or perhaps longer, with the last week in extreme conditions, but without the ICU treatment routinely available today, or (B) have an expected life of 78 years, with the last six months of heroics in an ICU. Faced with these constraints, who would pursue (even on religious grounds) a strategy that promises shorter life and longer period of pain? Collectively, however, we opt for choice B by providing end-of-life care without cost and by making it impossible (in the name of autonomy) for individuals to bind themselves by contracts from going back on their word when illness strikes. Some institutional firmness is desperately needed to resist the demands for care by persons who no longer reside behind the veil of ignorance. 
freely-available to those (often elderly) patients with especially severe or chronic conditions. ${ }^{43}$

Once Professor Jacoby answers these questions, she will have specified who is entitled to government-subsidized medical care, but she will still face the question of how that subsidy is to be delivered. Basically, government has a choice of providing the subsidized person with goods and services in kind or of providing the subsidized person with money (or something similar) that enables the subsidized person to purchase the goods and services in the private sector. ${ }^{44}$ Is it better for government to hire some doctors, nurses and others to work in government-owned hospitals, clinics, etc. (as in the Veterans Administration), or is it better for those people and assets to remain in the private sector with government paying some portion of their revenue $?^{45}$ And if Professor Jacoby prefers the latter option, should government pay providers of medical care directly (as in Medicare) or should it pay private insurers who, in turn, pay providers (as in the Massachusetts Plan)? In other words, should government provide the subsidized person with insurance or money to buy insurance?

43. See, e.g., Jost, supra note 37 , at 593 .

Though in the first instance [government healthcare] funds are often allocated by government or social insurance fund bureaucrats, in the end resources are often "rationed" at the patient level by health care professionals who decide how limited funds will be spent and services allocated.

If health care budgets are too constrained, as they have been historically in the United Kingdom and as they are reportedly for some services in Canada, rationing can become embarrassingly visible.

Id. at 593-94.

44. A third option is for government to mandate that private parties (such as employers, insurers or providers of medical care) bear the cost of providing the subsidy. Such "unfunded mandates" are rampant in the area of health care finance. An example is the Emergency Medical Treatment and Active Labor Act, which requires that any hospital that both maintains an emergency department and takes Medicare money to screen every patient coming to the emergency room and to stabilize any emergency medical condition found, without regard to the patient's ability to pay. 42 U.S.C. \$ 1395dd (2003). In my view, such an "unfunded mandate" is generally bad policy because it hides and spreads the subsidy's costs, which initially fall on providers of medical care but are then passed on to other patients and their insurers. See TERESA A. SULlIVAN, ELIZABETH WARREN \& JAY WESTBROOK, AS WE FORGIVE OUR DEBTORS 174-75 (1989). Why should these parties, rather than others in society, bear the costs of providing the subsidy? Even leaving aside these distributional concerns, transparency is better served by putting the subsidy on the government budget so "the parties that dictate the transfer payment are required to foot the bill." Richard A. Epstein, Living Dangerously: A Defense of Mortal Peril, 1998 U. ILL. L. REV. 909, 923 (1998). These distributional and transparency concerns counsel against unfunded mandates imposed, not just on providers of medical care, but also on other private parties, such as employers and insurers.

45. In other words, the choice is between a system similar to a national health system, such as Britain's, or a "social insurance" system, as is common in continental Europe. See Timothy Stoltzfus Jost, Why Can't We Do What They Do? National Health Reform Abroad, 32 J. L. MED. \& ETHICS 433, 433-35 (2004). 
In sum, Professor Jacoby has her work cut out for her. Her assertion that "medical-related financial distress" is a "pervasive problem," her desire to "make meaningful inroads into" the problems caused by "structural limitations of health care finance," ${ }^{47}$ have led her into a rich and challenging set of topics. I look forward to seeing how she addresses them.

46. Jacoby \& Warren, supra note 2, at 584 .

47. Id. at 563,584 . 
